Marquette University

e-Publications@Marquette

Social and Cultural Sciences Faculty Research and

Publications

Social and Cultural Sciences, Department of

$12-1-2011$

\title{
Gendered Violence and the Ethics of Social Science Research
}

Sameena A. Mulla

Marquette University, sameena.mulla@marquette.edu

Heather R. Hlavka

Marquette University, heather.hlavka@marquette.edu

Accepted version. Violence Against Women, Vol. 17, No. 12 (December 2011): 1509-1520. DOI. (C) 2011 SAGE Publications. Used with permission. 


\title{
Comment: Gendered Violence and the Ethics of Social Science Research
}

\author{
Sameena Mulla \\ Department of Social and Cultural Sciences \\ Marquette University \\ Milwaukee, WI \\ Heather Hlavka \\ Department of Social and Cultural Sciences \\ Marquette University \\ Milwaukee, WI
}

The issue of ethical conduct in research settings is important and complex. As tenure-track researchers who study gendered violence, we found Clark and Walker's discussion provocative, complex, and interesting. They urge researchers to attend both to the structural dynamics of research carried out under the pressures of tenure and promotion while advocating an ethical frame that draws attention to the limited definition of risk or harm that animates typical human subjects research. Victims of violence, they argue, should not be subjected to a standardized understanding of risk. A broader framework is needed, one which brings into conversation virtue ethics with consequentialist and ontological frameworks. Given the

Violence Against Women, Vol 17, No. 12 (December 2011): pg. 1509-1520. DOI. This article is (C SAGE Publications and permission has been granted for this version to appear in e-Publications@Marquette. SAGE Publications does not grant permission for this article to be further copied/distributed or hosted elsewhere without the express permission from SAGE Publications. 
impossible task of responding to the many points discussed by Clark and Walker, we chose to focus on four areas. In all likelihood, these areas of discussion reflect our own interests rather than Clark and Walker's, but challenged to think seriously about research ethics in victimization studies, we attend to the following points.

First, we seek to put virtue ethics in conversation with care ethics, in part because care ethics formed an important component of feminist discourse during the historical period in which institutional review boards came into being. While virtue ethics may have lost its masculinist inflection after shedding its etymological roots, ${ }^{i}$ care ethics was explicitly seen as suited for the feminist subject. Following our discussion of care ethics, we address the question of setting victims of violence apart as a special class of vulnerable human research subjects. We argue that such a designation may yield more problems than it does solutions. Next, we turn to the violence of epistemology as a concern in research ethics. How do we come to an ethical definition of the research object, and to whom are we accountable? Finally, we turn to the relation of care when carrying out ethically and methodologically sound research projects.

\section{Virtue Ethics, Feminism, and Care Ethics}

In their paper, Clark and Walker propose widening the frame of research ethics in victimization research by calling attention to the applicability of a virtues based ethics theory (p. 6) to address contemporary ethical demands that far exceed principle-based practice. In conflict with this position, the ethics framework that guides Western research is based on Kantian moral theory of the universal rational subject. Embedded in principle-based research ethics, United States Institutional Review Boards (IRBs) are charged with protecting the rights and safety of research participants primarily based on riskbenefit analyses. As Clark and Walker state, "Principlism's attraction is that rule-following allows researchers and institutions to believe they derive the benefits of rigorous, ethical thinking without needing to actually think about ethics" (p. 10-11). Debates about ethics and moral theory have a long history and not surprisingly, much of the original feminist research on ethics was published in the $1980 \mathrm{~s}$ coinciding with the establishment of many university IRBs. Certainly,

Violence Against Women, Vol 17, No. 12 (December 2011): pg. 1509-1520. DOI. This article is @ SAGE Publications and permission has been granted for this version to appear in e-Publications@Marquette. SAGE Publications does not grant permission for this article to be further copied/distributed or hosted elsewhere without the express permission from SAGE Publications. 
virtue ethicists and feminists alike have argued that ethical thinking provides a framework to guide decision making contrary to mere rules or regulations.

A discussion of ethical research practice with victims of violence must attend to the vast body of work on care ethics and virtue ethics. Feminist ethics developed in response to said universal standards of Western epistemology, arguing against established rational-choice frameworks based on objective/subjective binaries, reductive/deductive reasoning, and hierarchical relationships between the researcher and research "subject" (e.g., Gilligan 1982; Harding 1986, 1991; Harding and Norberg 2005; Noddings 1984; Smith 1987). This tension is embodied in the Kohlbeg and Gilligan debates that drew attention to moral decision making beyond obligation or principle. While Kohlberg (1981) argued that ethical and moral persons act out of universalist rights, virtues or obligations, Gilligan (1982) argued that decision making was also based on an ethic of care, privileging the relationship, particular, relative, and subjective over the principle, abstract, absolute, and objective. An ethic of care is complicated and contextual, and caring is affective rather than principled, depending on empathy and receptiveness (Noddings 1984). Virtue ethics focus on moral agents rather than actions, and emphasizes being and intention. Moral character then is privileged over consequence. In more recent literatures, ethicists have attempted to merge care ethics with virtue ethics. Debates center on their compatibility, definitions of care as virtue in terms of motives or consequences, relational ontology, and theories of justice (see Sander-Staudt 2006). While a thorough review of these debates is beyond the scope of this commentary, SanderStaudt (2006) distinguishes between the positioning of care in virtue ethics and care ethics, the pragmatism of care, and the distinct role of relational ontology. Ultimately, neither care ethics nor virtue ethics eliminates moral and ethical dilemmas. Rather, they are understood as models for researchers to draw upon in specific contexts of ethical complexity during the research process. Further, neither care nor virtue ethics excludes consideration of principle.

This long established scholarly debate, engaging with and challenging research hierarchies, remains focused on abstract principles rather than virtue or caring. Despite efforts to elucidate 
knowledge from particular standpoints (Keller 1985; DeVault 1999; Harding 1991; Smith 1987) the regulatory effect has been to err on the side of homogenization of the ethical approach and the research object. In fact, IRBs position participants as the "object" of study or the generalized "other," assuming shared, identifiable and consistent characteristics (e.g., defining and sampling a research population of victims). In the next section, we explore the complications attached to designating victims of violence as a special class of vulnerable human subjects.

\section{Victims of Partner Violence as a Class of Vulnerable Human Subjects}

Clark and Walker begin their call for a more broad approach to research ethics in research on victims of violence by expressing their concern over the lack of a specialized status of "vulnerable human subject" for victims of partner violence (p. 3). Though they do not explicitly argue that there ought to be such a designation in federal research regulations, its prominence within the article suggests that this is a serious consideration for Clark and Walker. The notion of victims of violence, specifically victims of intimate partner violence, as a specially designated class of vulnerable human subjects invites many questions. Invited to adopt a virtue ethics approach towards ethical comportment in research, we are urged to think of the character of the moral agent (p. 6). Within a given research setting, we can identify at least two moral agents: the researcher and the research participant. Clark and Walker thoroughly discuss the moral agency of researchers; hence, we turn our attention to the research participant. If we infer a suggestion to "ontologize" the subject from Clark and Walker's criticism of regulatory structures grounded in deontological theories ( $p$. 9 ), we can participate in the exercise of emphasizing the state of being described as "victim." Towards that end, the two primary questions we will pose here address the temporality and duration of victim status and the capacity of vulnerable subjects to consent to participate in research.

We come to these questions by direct comparison of victims of violence with the other classes of research subjects who carry a special designation as vulnerable research subjects within federal regulations.

Violence Against Women, Vol 17, No. 12 (December 2011): pg. 1509-1520. DOI. This article is C SAGE Publications and permission has been granted for this version to appear in e-Publications@Marquette. SAGE Publications does not grant permission for this article to be further copied/distributed or hosted elsewhere without the express permission from SAGE Publications. 
As Clark and Walker state, these include prisoners, pregnant women, fetuses, neonates and children. Typically, these designations are all bound within time. That is, there is a finite window in which one is a prisoner, a pregnant woman, a fetus, a neonate or a child. How long, then, does the status of victim of violence inhere? Are individuals who have experienced violence perpetually marked as victims for the duration of their lifetimes? Or are we only referring to individuals who are actively being victimized within an intimate partner setting at the time of their participation in the research project? Given that many studies are conducted in the aftermath of violence, particularly those studies that evaluate the role of legal and clinical interventions into violence, it seems that researchers encounter victims of violence at various temporal "distances" from the event (or an event) of victimization. Thus, the vulnerability of the subject would have to be assessed and reassessed unless one assumes it as a constant. In other words, the formula introduced by Clark and Walker would benefit from either a temporal "co-efficient" or a periodic recalculation (p. 18).

Faced with two equally untenable options, either casting victims in a permanent state of victimhood, or assigning a singular (temporal) criteria for leaving behind the status of victim, it becomes immediately apparent that classing victims of violence as a distinctive category is a slippery task. Feminist scholars have approached the question of the designations of "victim" from many different perspectives (Alcoff and Gray 1993; Lamb 1999; Mardorossian 2003). When do victims become survivors? What criteria are relevant in making this distinction? Who is empowered to make this distinction? These questions animate the debates over the meaning and permanence of victim status. For some, the identifiers "victim" or "survivor" can only be self-designated (Alcoff and Gray 1993: 262), while for others, continued deployment of the term "victim" is seen as paternalistic and diminishing of the agency of the subject (Lamb 1999: 9).

This points us to the question of agency of the research subject. Turning back to Clark and Walker's call to take seriously the moral agency of the ethical actors in a research setting, we must consider victims of violence as moral agents. Once again, comparing victims of violence to other classes of vulnerable human subjects proves a useful exercise. The vulnerability of prisoners, pregnant women, neonates,

Violence Against Women, Vol 17, No. 12 (December 2011): pg. 1509-1520. DOI. This article is (C SAGE Publications and permission has been granted for this version to appear in e-Publications@Marquette. SAGE Publications does not grant permission for this article to be further copied/distributed or hosted elsewhere without the express permission from SAGE Publications. 
fetuses and children is partly understood as a diminished capacity to consent to participate in research (Kipnis 2001; Zion, Gillam and Loff 2000: 616). Prisoners are seen as potentially coerced through the structural conditions of imprisonment. Pregnant women may not be attenuated to the added health risks of research, nor are they to commit to research participation that may harm the unborn-- the aforementioned fetuses and neonates who do not speak for "themselves." Children, who we view as agentive (Hlavka 2010; Prout 2000), are frequently considered to have a diminished capacity to consent because they have not attained an adult's faculty of reason and thus are unable to comprehend the potential harms and consequences that may unfold as a result of participate in research. If we consider the victim of violence in relation to her capacity to consent to participate in research, we see a danger in assuming that she has a diminished or impaired capacity to consent.

If we think about the interventions that typically attend intimate partner violence, the primary goal is often to empower the victim (Kasturirangan 2008). In cases of sexual violence, establishing and respecting the victim's capacity to consent is the very crux of both strategies to empower the victim as well as any legal case that subsequently unfolds. A rape victim within the setting of a formal intervention must consent to medical care and participation in the criminal justice process. Assuming a victim's diminished capacity to consent to participation in research requires us to differentiate between the victim as legal subject, medical subject, and potential research subject, fracturing the subject in a way that may prove epistemologically problematic in terms of our research agendas. Some may argue that research participation does not carry with it the same urgency and importance as accessing health care and reporting to the police, and this is a legitimate critique. However, it is here where our own research, respectively on children reporting sexual abuse and adult sexual assault forensic interventions, comes to bear.

Clark and Walker point out that victims of violence may come to have false expectations of the impact of the research in which they participate (p. 12-13). In our own experience, we have seen false expectations nurtured and encouraged not only by researchers, but by the legal and therapeutic establishments. For example, rape victims

Violence Against Women, Vol 17, No. 12 (December 2011): pg. 1509-1520. DOI. This article is @ SAGE Publications and permission has been granted for this version to appear in e-Publications@Marquette. SAGE Publications does not grant permission for this article to be further copied/distributed or hosted elsewhere without the express permission from SAGE Publications. 
who report to the police and undergo forensic examination are frequently surprised with the low rates of subsequent contact with the police department (Chen and Ullman 2010). Rather than disclose this statistical reality to victims, legal and medical personnel will frequently advocate and encourage victims to participate in the forensic examination and make a police report. Is the victim in these settings making an informed decision to consent? Within a virtue ethics frame, researchers should not participate in the same types of false promises in which we guarantee particular outcomes or impacts. It is impossible to anticipate our research findings, the success or failures of our dissemination plans, or the impact of our research. We are accountable for making full disclosures of these uncertainties so that research participants are empowered to make informed decisions to opt into or out of research. Such disclosures assist the victim as moral agent in making an informed decision. However, we think there is harm in assuming a diminished capacity of all victims of violence to consent-particularly in cases of sexual violence in which it is the capacity to consent which is itself being reaffirmed.

Finally, we face the challenge that the status and characteristics of victims, or particularly groups of victims, is frequently our research object. In studying victims, we embark on agendas of inquiry that query existing stereotypes or constructs of victimhood, and seek to illuminate underlying realities as opposed to validating a priori assumptions. Creating a regulatory designation that classes victims of violence as vulnerable research subjects introduces an a priori epistemological category, one which may predetermine our research findings and ultimately lead to the non-rigorous or problematic research findings of which Clark and Walker are deeply critical (p. 22). These are only one of several epistemological concerns Clark and Walker raise in their piece.

\section{Epistemic Violence and Ethnographic Directions}

Defining victims of violence as a particular class of subject is not the sole epistemological concern impacting research on intimate partner and sexual violence. In this section, we will address the dangers of epistemic violence, the potential of interdisciplinary research, and ethnographic methodologies. By addressing Stark's 
critique of clinical research on battered women's syndrome, Clark and Walker present a very unsettling picture of the dangers of epistemic violence (Spivak 1998: 280). Briefly, our understanding of epistemic violence, drawing on Spivak's classic example, is that of a subaltern defined by a Western epistemology that defines and delimits the subaltern's 'voice' in a way that does not encapsulate the subaltern's subject position as viewed from the subaltern's perspective. Here, both the subaltern's subjective position and their epistemological traditions are marginalized. Feminist standpoint theorists have addressed a similar range of concerns (Collins 1998; Smith 1999). Spivak does not limit epistemic violence to the context post-colonial studies, but draws particular attention to the vulnerability of women as research objects (Spivak 1998: 299). Women, she argues, are even more vulnerable to the epistemic violence of patriarchal Western constructs.

Let us now return to Clark and Walker's innate critique of epistemic violence in their introduction of Stark's research. Stark draws attention to the U.S. legal system's evidentiary standard derived from clinical research on battered women's syndrome, a standard that excludes many battered women whose presentations differ from the clinical profile advanced by researchers (p. 25). In this example, the narrowly defined research object, "battered women's syndrome," calcifies such that it acquires an epistemic solidity that defies flexibility, permeability and variation. Thus, a subject, the person suffering from battered women's syndrome, is produced through the narrowly defined criteria that limit the ways in which battered women's syndrome operates within the legal system. The violence of singular epistemic constructs extends beyond research contexts in which research comes to bear on interventions. In research on gender violence, ethical guidelines frequently suggest that research findings must be faithful enough to research participant's accounts that they are able to recognize their own narratives within the research outputs (Hall and Stevens 1991). This is particularly true where studies purport to represent the voices of victims. The potential for violence arises when victims, subjected to epistemic categories and understandings that do not fully encapsulate their experiences, do not recognize themselves in the research product (Mulla 2008). Thus, the battered women's syndrome survivors need never be denied access to this diagnosis in court in order to be harmed. Their experiences can be

Violence Against Women, Vol 17, No. 12 (December 2011): pg. 1509-1520. DOI. This article is @ SAGE Publications and permission has been granted for this version to appear in e-Publications@ Marquette. SAGE Publications does not grant permission for this article to be further copied/distributed or hosted elsewhere without the express permission from SAGE Publications. 
alienated and invalidated by the process of research itself. These undesirable outcomes are further complicated within research that seeks knowledge of victim subjectivity and meaning-making (Das and Kleinman 1997: 17; Kleinman 2006: 212). When the goal of a research study is to increase understanding of victim subjectivity and meaning-making practices, epistemic violence is both unethical and also failed research.

Avoiding the trap of designing a research methodology that is prone to epistemic violence is a challenge. Precision in defining our research objects is, indeed, frequently implicit in our desires for rigor. In our own research, how do we achieve the multi-stranded (or many fibered) modality of inquiry advocated by those like Wittgenstein (1957 §67 as cited in Clark and Walker)? Wittgenstein was fond of the comparison between the life-world and weaving, and alludes to this analogy at multiple points within the Philosophical Investigations (1957 §362). Thus, the pursuit of knowledge about the life-world was akin to unraveling the many fibers of a twined rope. Contrast this approach of unraveling with treating the rope as if it were one solid and singular object. Another analogy Wittgenstein uses within the Investigations is that of digging in the dirt. When we pick up a shovel to dig, he states, we could either think of ourselves as aiming to dig until we hit bedrock or simply turning over the earth (1957 §217). It is the second model, that of turning over the earth, that appeals to Wittgenstein. Aiming for bedrock may result in definitive and highimpact research, but it closes the door of future inquiry by presuming that there are no questions that ought to be pursued beyond the immediate research agenda. As with Stark's example of battered women's syndrome, such presumptions can result in a problematic and dangerous violence whereas continued inquiry would benefit scholars, research subjects, policy makers, and participants in the legal system.

Incorporating lessons from philosophy into the way we think about and conduct social science research is about far more than merely introducing a new jargon (Das 1998: 172). Philosophical concepts do not easily translate into social science thinking. Their potential contribution lies in helping researchers "to introduce a hesitancy in the way in which we habitually dwell among our concepts" (Ibid). If our approach to conducting research through a mode of

Violence Against Women, Vol 17, No. 12 (December 2011): pg. 1509-1520. DOI. This article is @ SAGE Publications and permission has been granted for this version to appear in e-Publications@Marquette. SAGE Publications does not grant permission for this article to be further copied/distributed or hosted elsewhere without the express permission from SAGE Publications. 
open-ended inquiry is the first step towards introducing hesitations that may lead to more ethical research, it has been our experience that interdisciplinary collaboration is a second constructive area in pursuing ethical research conduct with victims of violence. No single discipline has a monopoly on the study of intimate partner and sexual violence. Compelling research has been carried out by sociologists, criminologists, anthropologists, political scientists, social workers, psychologists, historians, and many others. Each discipline pursues different, though often overlapping, methodologies. There are many advantages and challenges to pursuing interdisciplinary collaboration and research, but again, we will limit our discussion to epistemic violence.

If the calcification and over-determination of research objects is what we seek to avoid, interdisciplinary research can aid us in approaching the research object through a deliberative process rather than succumb to the convenient habit of using a priori categories. Faced with an interlocutor who is oriented to a different epistemology than our own, we must justify the epistemic construct with which we are most familiar. There is also more incentive to diligently review a broader range of literature without the excuse of only working within one discipline, a problem to which Clark and Walker attend with great detail (p. 20). As an anthropologist and a criminologist working within sociological traditions, we frequently spend many frustrated hours setting a research agenda that can be justified within both of our home disciplines. Rather than regard this as burden, our experience has been that these deliberative processes lead to new and interesting approaches to the study of gendered violence in our society. For example, we have moved away from analyses of the event of violence itself-an epistemic object that does not easily lend itself to analysis, nor to generalizable findings. Instead, we find ourselves working in institutional structures that reify and validate particular experiences of suffering violence, such as the courtroom or the forensic examination (Mulla 2008).

A discussion of how we determine our epistemic constructs inevitability leads to consideration of the tendency of research structures to privilege so-called "scientific" models of research over other models. Scientific standards dictate which studies will be 
published and which excluded (p. 27). Applied research, Clark and Walker state, is given short shrift while clinical trials rule within medical journals. We argue for a broader understanding of the scientific method, one that embraces both experimental models while valuing the observational model, particularly as it applies to human behavior, culture and society. Observational science has a home within ethnographic methodology, an old tradition that replaces the certainties of the scientific experiment with the patience of longitudinal research plans, open-ended research questions, and a density and depth of data that can only be yielded through such long term commitments. There are risks that come with ethnographic researchas Stacey pointed out, in a more sustained research relationship there are more opportunities for ethical complications (Stacey 1988). There have been many thoughtful responses and objections to Stacey's regard of ethnography as problematic. What Stacey regards as increased risk through extended contact with research participants, we regard as increased accountability. Though short term research commitments may yield fewer immediate ethical violations in the interactions between researcher and research participant, in studying gendered violence, risk does not end in the moment the research encounter ends. Nor is the harm that may ensue limited only to the research participant, as Clark and Walker have already demonstrated. Thus, ethnographic models may allow for fruitful research processes that test the stability of research findings over longer periods of time, while engendering more reliable research objects that have withstood the course of longer research engagements. Ethnographers would be well-positioned to take up Clark and Walker's challenge to "imagine the daily life of, for example, a young woman who is being stalked, a penniless, battered mother of three small children living in a shelter, or a woman lying in a doorway after being raped and dumped in the street--these images might evoke the kind of care and curiosity that would lead to more fruitful scientific concerns embedded in a fundamental desire to not make their lives any worse" (p. 14). Attending to a more complete sense of the life-world of research subjects allows researchers an informed sense of the ethical issues at hand.

Violence Against Women, Vol 17, No. 12 (December 2011): pg. 1509-1520. DOI. This article is (C SAGE Publications and permission has been granted for this version to appear in e-Publications@Marquette. SAGE Publications does not grant permission for this article to be further copied/distributed or hosted elsewhere without the express permission from SAGE Publications. 


\section{Care as an Epistemological Cornerstone}

Controversies about relations between knowledge and power in research methods and practices have long been teased out in feminist and social theory. Epistemological questions have included: What is knowledge? Whose knowledge is it? Who decides what problems and conditions are worthy of study? How is knowledge produced and disseminated? Feminists from varying perspectives have pointed to possible solutions including standpoint theory, mentioned earlier, and participatory action research. Though unable to eliminate power differentials, these methodologies work to address the power relations between researcher and research participants and their communities. Clark and Walker, too, invite researchers to address the ethics of the entire research enterprise (p. 30) including the research purpose and design, staff training and education, and research publication. From this position, the research enterprise ought to then privilege contextual, experientially-based knowledge and intersubjectivity (Fonow and Cook 1991; Stanley and Wise 1993). We argue that the moral agent must be intentional, reflexive and imaginative in a prolonged process of ethical and moral query that attends to both motive and to ends. She cannot be content with questions of being and intention.

Privileging both intention and outcome embeds the entire research process in a relational, reflexive, and at times, transformative endeavor. Viewing this process as intersubjective problematizes how the researcher might go about, intentionally, her scientific practice without attending to a chorus of voices and shared meanings. Ethical research practice will largely depend on the qualities and skills of the researcher(s). Such skills stress interdependence and responsibility and include respect, empathy, imagination, authenticity and as Clark and Walker state, adaptive thinking (p. 29). Ethical practice constitutes a host of activities not limited to: immersing oneself in the literature; dwelling on discussions and controversies in the field (such as calls for research on women's violent behavior in relationships [Renzetti 1999]; same-sex relationship violence; and men as victims of partner violence); anticipating potential ethical conundrums during the course of research and possible responses; encouraging and developing the reflexivity necessary to question the consequences of 
one's position and biography in relation to others, the research environment, and the broader academic enterprise; engaging in the dialogic exercise of learning from the reflexive research practices of others; and allowing participants and their embodied communities to take part in the research process including informing the research problem and process to be studied (e.g., participatory action research), informing staff training and education (e.g., Campbell et al. 2009) as well as the final research product.

Shifting focus away from a hierarchical, detached and objective relationship to one of virtue, care and connectedness requires flexibility. Surely we are all aware of the extent to which the researcher is never in full control of her research process, participants, or environment. With new knowledges that recognize the intersectional identities of victims of partner violence, we must be prepared for an ever shifting field of study and thus, unstable "population" characteristics. Contrary to Kohlberg's universalist virtues, we argue that virtues, too, are engendered in communities and are grounded in particular times and locations. Without detracting from the importance of literature reviews, part of a reflexive and relational practice must account for the fluidity of identity. We argue that it is untenable at best, to quantifiably rank said characteristics to form vulnerability classifications. Instead, these countless contingencies and complexities ought to be embraced and reflected in research projects and designs and can be assessed in part by the literature, practice communities, and field experiences of both research participants and researchers (e.g., Campbell 2002; Campbell et al. 2009). Finally, we briefly return to Clark and Walker's concerns about the role of scientific journals and how they directly bear upon the ethical outcomes and the practice of care. Clark and Walker point to barriers to publication on partner violence in high impact and mainstream journals (pp. 27-28). This issue also extends beyond the research environment to larger practice communities. The positionality and biography of the researcher plays a central role in the final text (analysis, interpretation, evaluation) and dissemination of research. How will participants be represented? Who will receive the information and in what form? Approaching such questions from a care ethics framework adds an additional layer. Who likely engages in the practice of care and justice with victims of partner violence? The practice of giving and receiving care - whether

Violence Against Women, Vol 17, No. 12 (December 2011): pg. 1509-1520. DOI. This article is (C SAGE Publications and permission has been granted for this version to appear in e-Publications@Marquette. SAGE Publications does not grant permission for this article to be further copied/distributed or hosted elsewhere without the express permission from SAGE Publications. 
we consider research, publication, education or service - is not gender-neutral. The dissemination of "care" research then closely accords with wider care practices and can be more deeply challenged along these lines. We invite researchers to use explicitly gendered and structural frameworks to explore journal hierarchies and information dissemination strategies.

\section{Conclusion}

Clark and Walker have issued a worthwhile challenge to all researchers to widen the lens of research ethics in our work with victims of violence. Lest it seem that we are advocating the substitution of one ethical lens, that of virtue ethics, with another, that of care ethics, we suggest that no single ethical tradition is sufficient to the task of maintaining high ethical standards for research conduct. These tools, for one, come to us from philosophy, whereas we are functioning in the world of ideas as well as in our own complex lifeworlds and those of our research participants. We view these participants as legitimate stakeholders within these research processes-the studies we publish are accountable to their critiques and understandings. When we purport to study victimization, we must consider the intersubjective construction of the category "victim"-this imperative is both to the benefit of our ethical standards as well as our research standards. To suspect the victim of violence as possessing a compromised capacity to consent is deeply problematic, again from both an epistemological and an ethical standard. Finally, sustained contact with research participants enables more accountability and allows for longitudinal scrutiny of the research object as well as research findings. Such regard for our research participants and the incorporation of ethnographic methodology, as well as interdisciplinary collaboration, will help us avoid epistemic violence. While we may never come to perfect solutions in our desire to attain high standards of ethical conduct, we can at least do as Das (1998) asks and give our research participants the benefit of our deliberate hesitation as we engage in the enterprise of research.

Violence Against Women, Vol 17, No. 12 (December 2011): pg. 1509-1520. DOI. This article is @ SAGE Publications and permission has been granted for this version to appear in e-Publications@Marquette. SAGE Publications does not grant permission for this article to be further copied/distributed or hosted elsewhere without the express permission from SAGE Publications. 
NOT THE PUBLISHED VERSION; this is the author's final, peer-reviewed manuscript. The published version may be accessed by following the link in the citation at the bottom of the page.

\section{References}

Alcoff, L. \& L. Gray. (1993). "Survivor discourse: Transgression or recuperation?" Signs. 18(2), 260-290.

Campbell, R. (2002). Emotionally involved: The impact of researching rape. New York, NY: Routledge.

Campbell, R., A. Adams, S. Wasco, C. Ahrens \& T. Self. (2009). "Training interviewers for research on sexual violence: A qualitative study of rape survivors' recommendations for interview practice." Violence Against Women, 15, 595-617.

Chen, Y. \& S.E. Ullman. (2010). "Women's reporting of sexual and physical assaults to police in the national violence against women survey," Violence Against Women, 16(3), 262-279.

Das, V. (1998). "Wittgenstein and anthropology," Annual Review of Anthropology. 27, 171-195.

Das, V. \& A. Kleinman. (1997). "Introduction," In Violence and subjectivity. V. Das, A. Kleinman, M. Ramphele and P. Reynolds, eds. Berkeley, CA: University of California Press, p. 1-17.

DeVault, M.L. (1999). Liberating method: feminism and social research. Philadelphia: Temple University Press.

Collins, P.H. (1998). Fighting words: Black women and the search for justice. Minneapolis, MN: University of Minnesota Press.

Fonow, M.M. \& J.A. Cook, eds. (1991). Beyond methodology: Feminist scholarship as lived research. Bloomington: Indiana University Press.

Gilligan, C. (1982). In a different voice: Psychological theory and women's development. Cambridge, MA: Harvard University Press.

Hall, P.E. \& J. M. Stevens. 1991. "Rigor in Feminist Research," Advances in Nursing. 13(3), 16-29.

Harding, S. (1986). The science question in feminism. Ithaca, NY: Cornell University Press.

-----. 1991. Whose science? Whose knowledge? Thinking from women's lives. Ithaca, NY: Cornell University Press.

Harding, S.\& K.Norberg. (2005). "New feminist approaches to social science methodologies: An introduction." Signs, 30(4), 2009-2015.

Hlavka, H. (2010). "Child sexual abuse and embodiment," in Children and youth speak for themselves. H. Johnson, ed. Bingley, UK: Emerald Group Publishing, Ltd., pp. 131-166.

Kasturirangan, A. (2008). "Empowerment and programs Designed to address domestic violence," Violence Against Women. 14(12), 1465-1475.

Keller, E.F.. (1985). Reflections on gender and science. New Haven: Yale University Press.

Kipnis, K. (2001). "Vulnerability in research subjects: A bioethical taxonomy," in Ethical and policy issues in research involving human participants,

Violence Against Women, Vol 17, No. 12 (December 2011): pg. 1509-1520. DOI. This article is (C SAGE Publications and permission has been granted for this version to appear in e-Publications@Marquette. SAGE Publications does not grant permission for this article to be further copied/distributed or hosted elsewhere without the express permission from SAGE Publications. 
NOT THE PUBLISHED VERSION; this is the author's final, peer-reviewed manuscript. The published version may be accessed by following the link in the citation at the bottom of the page.

volume 2. Commissioned Paper. Bethesda, MD: National Bioethics Advisory Commission, pp. G1-G13.

Kleinman, A. (2006). What really matters: Living a moral life amidst uncertainty and danger. Oxford, UK and New York, NY: Oxford University Press.

Kohlberg, L. (1981). Essays on moral development: vol. 1. The philosophy of moral development: Moral stages and the idea of justice. New York: Harper and Row.

Lamb, S. (1999). New versions of victims: Feminists struggle with the concept. New York: New York University Press.

Mardorossian, C. (2003). "Towards a new feminist theory of rape," Signs. 27(3), 743-775.

Mulla, S. (2008). "There is no place like home: The body as the scene of the crime in sexual assault intervention," Home Cultures. 5(3), 301-326.

Noddings, N. (1984). Caring: A feminine approach to ethics and moral education. Berkeley: University of California Press.

Prout, A. (2000). "Childhood bodies: Construction, agency and hybridity," In The body, childhood and society, A. Prout, ed. New York: Palgrave Macmillan, pp. 1-18.

Renzetti, C. (1999). "The challenge to feminism posed by women's use of violence in intimate relationships." In S. Lamb (Ed.), New versions of victims (pp. 42-56). New York: New York University Press.

Sander-Staudt, M. (2006). "The unhappy marriage of care ethics and virtue ethics." Hypatia, 21, 21-39.

Smith, D. (1987). The everyday world as problematic: A feminist sociology. Boston: Northeastern University Press.

---. 1999. Writing the social: Critique, theory, and investigations. Toronto: University of Toronto Press.

Spivak, G.C., (1998). "Can the subaltern speak?" In Marxism and the interpretation of culture, C. Nelson and R. Grossberg, eds. Urbana and Chicago, IL: University of Illinois Press, pp. 271-315.

Stacey, J. (1988). "Can there be a feminist ethnography?" Women's Studies International Forum. 11(1), 21-27.

Stanley, L. \& S. Wise. (1993). Breaking out again: Feminist ontology and epistemology. London and New York: Routledge.

Wittgenstein, L. 1957. Philosophical investigations. G.E.M. Anscombe, trans. Oxford, UK and Malden, MA: Blackwell Publishers.

Zion, D., L. Gillam \& B. Loff. 2000. "The declaration of Helsinki, CIOMS and the ethics of research on vulnerable populations," Nature Medicine $6(6), 615-617$.

' Vir is Latin for man. Virtue indicated qualities of manliness. In the Aristotelian tradition, all free males had the potential to become

Violence Against Women, Vol 17, No. 12 (December 2011): pg. 1509-1520. DOI. This article is (C SAGE Publications and permission has been granted for this version to appear in e-Publications@Marquette. SAGE Publications does not grant permission for this article to be further copied/distributed or hosted elsewhere without the express permission from SAGE Publications. 
NOT THE PUBLISHED VERSION; this is the author's final, peer-reviewed manuscript. The published version may be accessed by following the link in the citation at the bottom of the page.

virtuous. Though the contemporary concept of virtue theory has drifted away from Aristotle's roots, its predisposition towards masculine ideals is part of its genealogy.

Violence Against Women, Vol 17, No. 12 (December 2011): pg. 1509-1520. DOI. This article is (C SAGE Publications and permission has been granted for this version to appear in e-Publications@Marquette. SAGE Publications does not grant permission for this article to be further copied/distributed or hosted elsewhere without the express permission from SAGE Publications. 